\title{
CD103 Expression on Blastic Plasmacytoid Dendritic Cell Neoplasms in Peripheral Blood and Bone Marrow Samples
}

Received: 02 March, 2020

Accepted: 30 April, 2020

Published: 01 May, 2020

*Corresponding author: Ron Lee, MD, Esoterix Pathology Practice Group, Brentwood TN, USA, E-mail: ronlee100@outlook.com

https://www.peertechz.com

Check for updates

\author{
Ron Lee ${ }^{1 *}$, Sally Ullery ${ }^{2}$ and Ron Thomason ${ }^{1}$ \\ ${ }^{1}$ Esoterix Pathology Practice Group, Brentwood TN, USA \\ ${ }^{2}$ Integrated Oncology, Brentwood TN, USA
}

\begin{abstract}
Blastic Plasmacytoid Dendritic Cell Neoplasm (BPDCN) is an aggressive neoplasm which is typically CD4+, CD56+, and CD123+. There is limited information regarding CD103 expression on blastic plasmacytoid dendritic cell neoplasms. We identified six cases of BPDCN and all six had at least partial CD103 expression (31-92\% positive) with the majority having significant expression of CD103.
\end{abstract}

\section{Introduction}

Blastic Plasmacytoid Dendritic Cell Neoplasm (BPDCN) is an aggressive neoplasm with distinctive immunophenotypic features and limited treatment options. Case reports and reviews typically describe $\mathrm{BPDCN}$ as $\mathrm{CD} 4+, \mathrm{CD} 56+$, and $\mathrm{CD} 123+$, but there is limited and conflicting literature regarding CD103 expression on BPDCN. Here we report our experience with CD103 expression on cases of BPDCN in peripheral blood and bone marrow samples. To our knowledge, this is the only series of such cases specifically characterizing CD103 expression on BPDCN. This information may be useful with respect to the diagnosis, prognosis, and/or treatment of BPDCN (e.g. antiCD103 therapy).

\section{Materials and methods}

Cases of blastic plasmacytoid dendritic cell neoplasm were identified by manual tracking and supplemented by using a word search for "blastic plasmacytoid dendritic" in either the Interpretation or Comment fields of completed flow cytometry reports for peripheral blood and bone marrow specimens. Six cases of peripheral blood and bone marrow samples submitted to our facility since 2015 were identified which were consistent with blastic plasmacytoid dendritic cell neoplasm based on immunophenotypic, clinical, and morphologic findings and had $\mathrm{CD} 103$ performed (all were $\mathrm{CD}_{4+}+\mathrm{CD} 56+, \mathrm{CD} 123+$ ). Tissue samples were excluded as $\mathrm{CD} 103$ was not performed on tissue samples.

Samples were processed according to standard accepted flow cytometry protocols. Multicolor flow cytometry was performed using an 8 color panel of Becton Dickinson antibodies with samples run on Becton Dickinson FCSCanto II flow cytometers (Table 1). Analysis of data was performed with FSC express (De Novo Software) and WinList (Verity Software House) software.

For determination of $\mathrm{CD} 103$ expression, abnormal cells were gated using CD45 v SSC and CD4 v SSC; internal lymphocytes in the same tube were used for negative controls and confirmed with another negative marker, CD23, in separate tubes (Figures 1,2). The values were compared using the Student's T-test (Microsoft Office Excel).

\section{Results}

Of the six cases identified, two were peripheral blood samples and four were bone marrow samples (Table 2). The cases included three males and three females with an age range of 24-91 years (average 59). Three cases presented with pancytopenia, one with a history of myeloid sarcoma of skin, 
Table 1: 8 color antibody panel, clones and isotypes, Becton Dickinson.

\begin{tabular}{|c|c|c|c|c|c|c|c|c|}
\hline 8-Color Panel & FL1 & FL2 & FL3 & FL4 & FL5 & FL6 & FL7 & FL8 \\
\hline Tube & FITC & PE & PerCP-Cy5.5 & PE-Cy7 & APC & APC-H7 & V450 & V500 \\
\hline Tube 1 & CD2 & CD7 & CD16 & $\mathrm{x}$ & CD56 & CD45 & CD3 & $x$ \\
\hline Clone & S5.2 & M-T701 & $3 G 8$ & & NCAM16.2 & 2D1 & UCHT1 & \\
\hline Isotype & $\lg G 2 a$ & $\operatorname{lgG} 1$ & $\operatorname{lgG} 1$ & & $\lg G 2 b$ & $\lg \mathrm{G} 1$ & $\operatorname{lgG} 1$ & \\
\hline Tube 2 & CD57 & CD103 & CD4 & $\mathrm{CD} 8$ & CD11c & CD45 & $\mathrm{CD} 3$ & CD20 \\
\hline Clone & HNK-1 & Ber-ACT8 & SK3 & SK1 & S-HCL-3 & 2D1 & UCHT1 & L27 \\
\hline Isotype & $\lg M$ & $\operatorname{lgG1}$ & $\lg G 1$ & $\lg G 1$ & $\lg G 2 b$ & $\lg G 1$ & $\lg G 1$ & $\lg \mathrm{G} 1$ \\
\hline Tube 3 & FMC-7 & CD23 & CD19 & CD5 & CD38 & CD45 & CD3 & $x$ \\
\hline Clone & FMC7 & EBVCS-5 & SJ25C1 & L17F12 & HB-7 & 2D1 & UCHT1 & \\
\hline Isotype & $\lg M$ & $\operatorname{lgG} 1$ & $\lg \mathrm{G} 1$ & $\lg G 2 a$ & $\lg \mathrm{G} 1$ & $\lg \mathrm{G} 1$ & $\lg G 1$ & \\
\hline Tube 4 & CD22 & Lambda & CD19 & CD10 & Kappa & CD45 & CD5 & CD20 \\
\hline Clone & 1-155-2 & S-HCL-1 & SJ25C1 & $\mathrm{HI} 10 \mathrm{a}$ & TB28-2 & 2D1 & L17F12 & $\mathrm{L} 27$ \\
\hline Isotype & $\operatorname{lgG} 1$ & $\operatorname{lgG} 2 b$ & $\lg \mathrm{G} 1$ & $\operatorname{lgG} 1$ & $\lg G 1$ & $\lg G 1$ & $\operatorname{lgG} 2 a$ & $\lg \mathrm{G} 1$ \\
\hline Tube 5 & CD15 & CD64 & CD16 & CD33 & CD13 & CD45 & CD14 & $x$ \\
\hline Clone & HI98 & MD22 & $3 \mathrm{G} 8$ & P67.6 & WM15 & 2D1 & MOP9 & \\
\hline Isotype & $\lg M$ & $\operatorname{lgG} 1$ & $\operatorname{lgG} 1$ & $\operatorname{lgG} 1$ & $\operatorname{lgG} 1$ & $\operatorname{lgG} 1$ & $\lg G 2 b$ & \\
\hline Tube 6 & CD38 & CD11b & CD34 & CD117 & CD13 & CD45 & HLA-DR & CD20 \\
\hline Clone & HB-7 & D12 & $8 \mathrm{G} 12$ & 104D2 & WM15 & 2D1 & L243 & L27 \\
\hline Isotype & $\lg G 1$ & $\operatorname{lgG} 2 a$ & $\lg G 1$ & $\lg G 1$ & $\lg G 1$ & $\lg G 1$ & $\lg G 2 a$ & $\lg G 1$ \\
\hline Tube 7 & & & 7-AAD & & & & & \\
\hline
\end{tabular}

A.

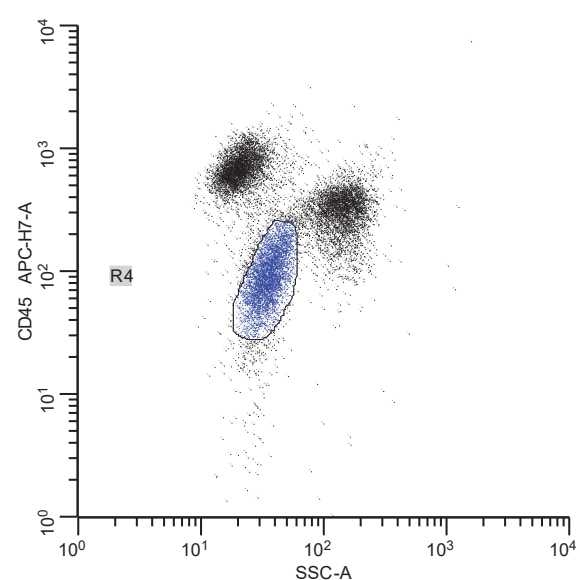

B.

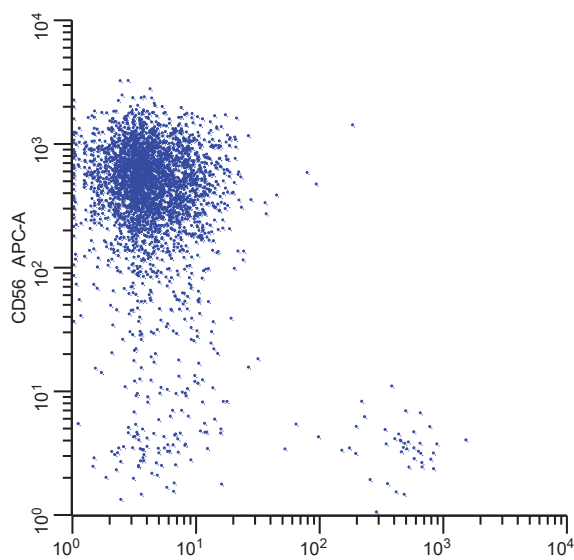

C.

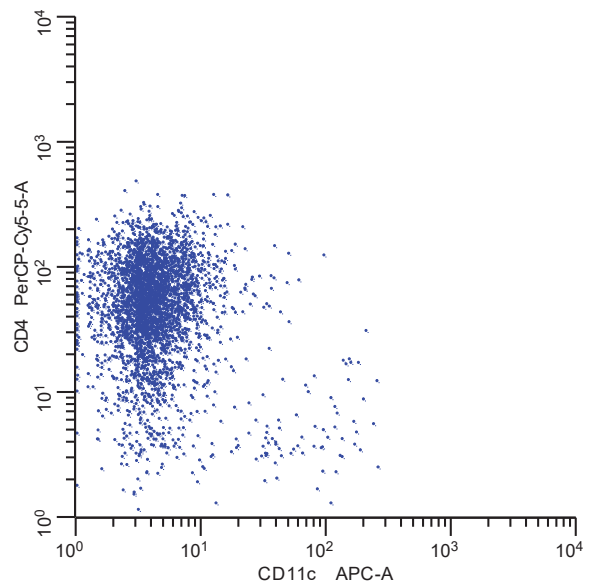

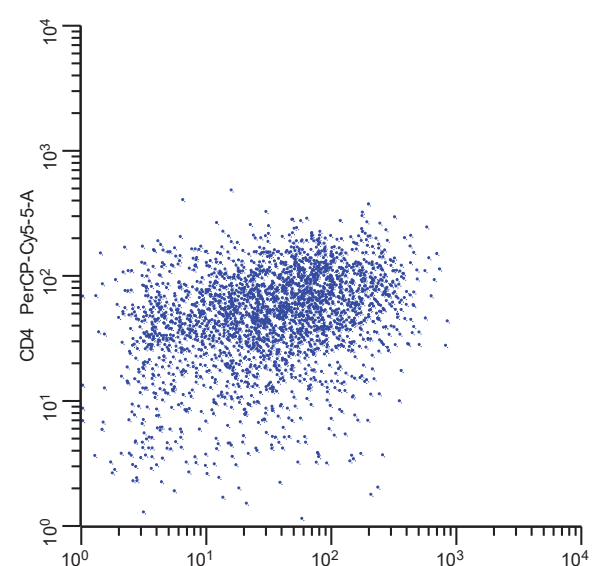

D.

Figure 1: Abnormal cells. A. Abnormal cells in blast region. B. Abnormal cells are CD56+. C. Abnormal cells are CD4+. D. Abnormal cells are CD103+

Citation: Lee R, Ullery S, Thomason R (2020) CD103 Expression on Blastic Plasmacytoid Dendritic Cell Neoplasms in Peripheral Blood and Bone Marrow Samples. Arch Hematol Case Rep Rev 5(1): 006-010. DOI: https://dx.doi.org/10.17352/ahcrr.000022 
A.

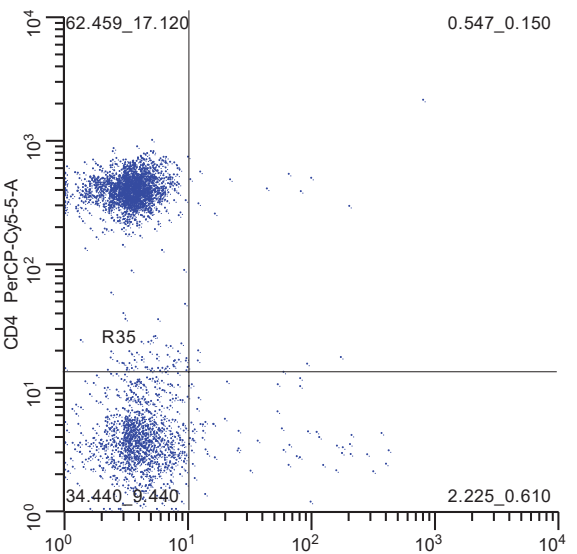

CD103 PE-A

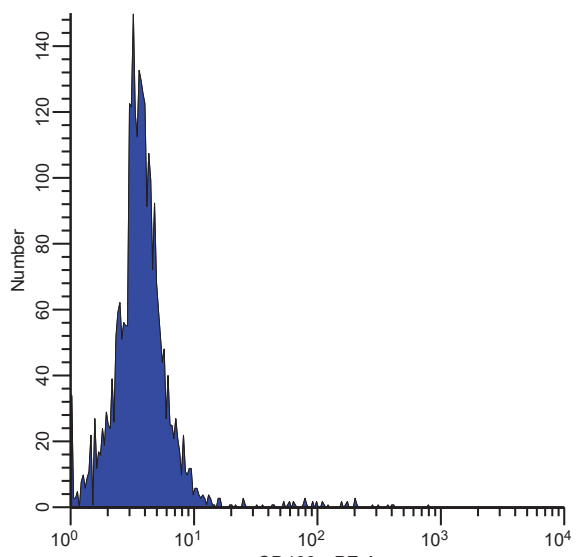

C.

CD 103 PE-A

D.

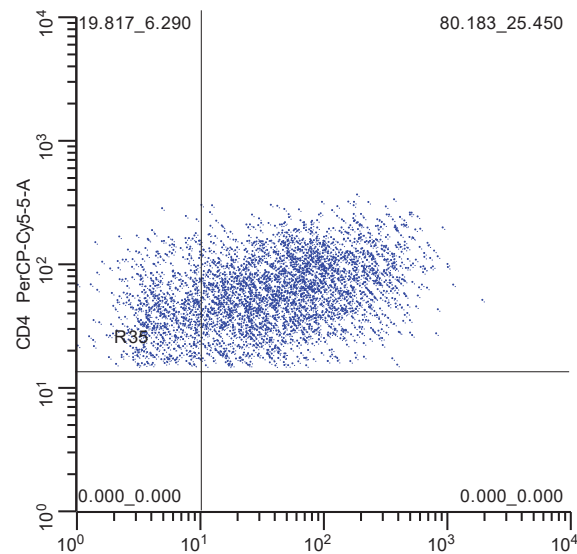

B.

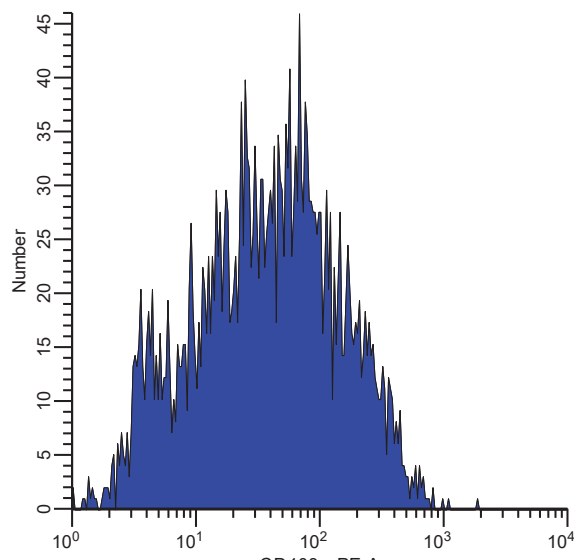

Figure 2: CD103 on abnormal cells compared to negative control control (lymphocytes. A. Dotplot for CD103 on lymphocytes. B. Dotplot for CD103 on abnormal cells C. CD103 median fluorescence on lymphocytes. D. CD103 median fluorescence on abnormal cells.

Table 2: Patient Demographics.

\begin{tabular}{|c|c|c|c|c|}
\hline & Age & Sex & Sample & History \\
\hline 1 & 24 & $\mathrm{~F}$ & Peripheral Blood & $\begin{array}{l}\text { Severe microcytic, hypochromic } \\
\text { thrombocytopenia, immature W } \\
\text { type } 2 \text { diabetes, gluteal lesion }\end{array}$ \\
\hline 2 & 91 & $\mathrm{M}$ & Peripheral Blood & Shortness of breath, skin lesions \\
\hline 3 & 61 & $\mathrm{M}$ & $\begin{array}{c}\text { Bone Marrow } \\
\text { Aspirate }\end{array}$ & Myeloid sarcoma involving skin \\
\hline 4 & 41 & $\mathrm{M}$ & $\begin{array}{c}\text { Bone Marrow } \\
\text { Core }\end{array}$ & New pancytopenia \\
\hline 5 & 57 & $\mathrm{~F}$ & $\begin{array}{c}\text { Bone Marrow } \\
\text { Aspirate }\end{array}$ & Pancytopenia \\
\hline 6 & 80 & $F$ & $\begin{array}{c}\text { Bone Marrow } \\
\text { Aspirate }\end{array}$ & Pancytopenia \\
\hline
\end{tabular}

Average

59 
one with shortness of breath and skin lesions on the back and abdomen, and one with severe microcytic, hypochromic anemia, thrombocytopenia, immature WBCs suggestive of blasts, type 2 diabetes, and a gluteal lesion.

The percentage of blastic plasmacytoid dendritic cells detected ranged from $1-85 \%$ (average 36\%) (Table 3). The abnormal cells from all six cases displayed CD103 expression, ranging from $31-92 \%$ positive (average $72 \%$ ). The geometric mean CD103 fluorescence ranged from 21-229 (average 77) and the median CD103 fluorescence ranged from 19-265 (average 80). Negative control $\mathrm{CD} 103$ fluorescence ranged from 3.15.9 (mean, average 4.5) and 3.3-6.2 (median, average 4.6). The average mean and median fluorescence were 17 times greater than the average negative control (range 4-43 times). The differences between the mean and median values for the abnormal cells compared to controls were statistically significant ( $\mathrm{P} 0.02$ for geometric mean and 0.04 for median fluorescence).

For each sample, \% of abnormal cells in the sample, \% CD103 positive, and mean and median fluorescent values for the abnormal populations and negative controls are shown; $\mathrm{P}$ values for differences between the mean and median values for abnormal cells compared to controls are also shown.

\section{Discussion}

CD103 (HML-1, Integrin aE-subunit) functions as an adhesion molecule and has a role in cell signaling, adhesion and migration on T-cells [1,2]. It is expressed by intraepithelial $\mathrm{T}$-cells, some peripheral regulatory $\mathrm{T}$-cells, lamina propria T-cells, and a subset of normal dendritic cells [3-7]. With respect to neoplastic entities, it is typically expressed in cases of hairy cell leukemia, hairy cell variant, and enteropathic $\mathrm{T}$-cell lymphoma but may also be seen in some cases of precursor T-cell neoplasms, large B-cell lymphoma, and B-cell prolymphocytic leukemia [8]. While the immunophenotypic of expression of $\mathrm{CD} 4, \mathrm{CD} 56$, and $\mathrm{CD} 123$ is well documented on blastic plasmacytoid dendritic cell neoplasms, literature regarding expression of $\mathrm{CD} 103$ is limited, some references refer to $\mathrm{CD} 303$ positivity, and there are reports which indicated absence of $\mathrm{CD} 103$ on blastic plasmacytoid dendritic cell neoplasms [9-11].

Normal dendritic cells play an important role in immunity as antigen presenting cells and modulators in immune responses. The cell of origin of blastic plasmacytoid dendritic cell neoplasms is presumed to be plasmacytoid dendritic cells based on the expression of certain markers, production of interferon, maturation capacity, and molecular profiling [12]. As $\mathrm{CD} 103$ is expressed on a subset of normal dendritic cells,

Table 3: Abnormal cells compared to controls

$\begin{array}{llc} & \text { Abnormal cells } & \text { CD103 \% } \\ \text { Case } & \text { (\% of sample) } & \text { positive }\end{array}$

1
80

92

4

(

Average

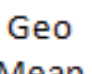

Mean

55

229

55

30

21

74

77

\section{Median}

Mean

Control
Median

\section{Control}

$3.7 \quad 3.7$

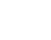

P value 
it is not surprising to find the expression of $\mathrm{CD} 103$ on blastic plasmacytoid dendritic cell neoplasms.

Blastic plasmacytoid dendritic cell neoplasms are aggressive and typically treated with leukemia protocols such as an ALL-based regimen (HCVAD alternating with methotrexate and ARA-C) [13,14]. Anti-CD123 has been used and the FDA approved tagraxofusp-erzs (ELZONRIS, Stemline Therapeutics), a CD123-directed cytotoxin, for blastic plasmacytoid dendritic cell neoplasm (BPDCN) in adults and in pediatric patients 2 years and older on Dec 21, 2018. An antiCD103 antibody drug conjugate has been used experimentally in mice but has not been used in humans [15]. Given our findings, an anti-CD103 therapy may be worth exploring for cases of blastic plasmacytoid dendritic cell neoplasms demonstrated to be $\mathrm{CD} 103+$.

Our limited series of blastic plasmacytoid dendritic cell neoplasms in peripheral blood and bone marrow samples shows significant expression of CD103. CD103 expression on blastic plasmacytoid dendritic cell neoplasms may have implications for diagnosis, prognosis, and treatment (e.g. anti-CD103 therapy). Future studies should further evaluate CD103 expression in cases of blastic plasmacytoid dendritic cell neoplasms and whether tissue cases also express CD103.

\section{References}

1. Cepek KL, Shaw SK, Parker CM, Russell GJ, Morrow JS, et al. (1994) Adhesion between epithelial cells and $\mathrm{T}$ lymphocytes mediated by E-cadherin and the alpha E beta 7 integrin. Nature 372: 190-193. Link: https://bit.ly/2yWLaFG

2. Dustin ML, Garcia-Aguilar J, Hibbs ML, Larson RS, Stacker SA, et al. (1989) Structure and regulation of the leukocyte adhesion receptor LFA-1 and its counterreceptors, ICAM-1 and ICAM-2. Cold Spring Harb Symp Quant Biol 54 753-765. Link: https://bit.ly/2YmyzG

3. Scott CL, Aumeunier AM, Mowat AM (2011) Intestinal CD103+ dendritic cells: master regulators of tolerance? Trends in Immunology 32: 412-419. Link: https://bit.ly/2WeOPsd

4. Darren Thomas Ruane, Ed C. Lavelle (2011) The Role of CD $103^{+}$Dendritic
Cells in the Intestinal Mucosal Immune System. Front Immunol 2: 25. Link: https://bit.ly/2WjwjwY

5. Lehmann J, Huehn J, La Rosa MD, Maszyna F, Kretschmer U, et al. (2002) Expression of the integrin alpha Ebeta 7 identifies unique subsets of CD25+ as well as CD25- regulatory T-cells. Proc Natl Acad Sci USA 99: 13031-13036. Link: https://bit.ly/3f8tR5b

6. Aziz S, Fackler OT, Meyerhans A, Müller-Lantzsch N, Zeitz M, et al. (2005) Replication of M-tropic HIV-1 in activated human intestinal lamina propria lymphocytes is the main reason for increased virus load in the intestinal mucosa. J Acquir Immune Defic Syndr 3: 23-30. Link: https://bit.ly/2SpU6dt

7. Johansson-Lindbom B, Svensson M, Pabst O, Palmqvist C, Marquez G, et al. (2005) Functional specialization of gut CD103+ dendritic cells in the regulation of tissue-selective T cell homing. J Exp Med 202: 1063-1073. Link: https://bit.ly/2SowHZT

8. Ortolani C (2011) Flow Cytometry of Hematological Malignancies, WileyBlackwell. 89-90, 174-175, and 187. Link: https://bit.ly/2SozN06

9. Fanny J, Stephane D, Gerard D, Brigitte B, Béatrice V, et al. (2014) Blastic Plasmacytoid Dendritic Cell Neoplasms: Clinico-immunohistochemical Correlations in a Series of 91 Patients. The American Journal of Surgical Pathology. 38: 673-680. Link: https://bit.ly/3cWCvlo

10. Shi Y, Wang E (2014) Blastic plasmacytoid dendritic cell neoplasm: a clinicopathologic review. Arch Pathol Lab Med 138: 564-569. Link: https://bit.ly/2YlgnwP

11. Sahin DG, Akay OM, Teke HU, Andic N, Gunduz E, et al. (2013) Blastic plasmacytoid dendritic cell leukemia successfully treated by autologous hematopoietic stem cell transplantation to a remission of 48-month duration. Case Rep Hematol 2013: 471628. Link: https://bit.ly/3aWQSVk

12. Jaffe (2017) Hematopathology, Second Edition. Chapter 51, Blastic Plasmacytoid Dendritic Cell Neoplasm.

13. Sullivan JM, Rizzieri DA (2016) Treatment of blastic plasmacytoid dendritic cell neoplasm, Hematology Am Soc Hematol Educ Program 16-23. Link: https://bit.ly/2SrF4UN

14. Pemmaraju N, Konopleva M (2018) Treating Blastic Plasmacytoid Dendritic Cell Neoplasm. The Hematologist 15: 5. Link: https://bit.ly/2VRLr5D

15. Da Xue, Pili Liu, Wangming Chen, Chi Zhang, Lei Zhang (2019) An anti-CD103 antibody-drug conjugate prolongs the survival of pancreatic islet allografts in mice. Cell Death Dis. 10: 735. Link: https://go.nature.com/2YtU0Fs

Discover a bigger Impact and Visibility of your article publication with

Peertechz Publications

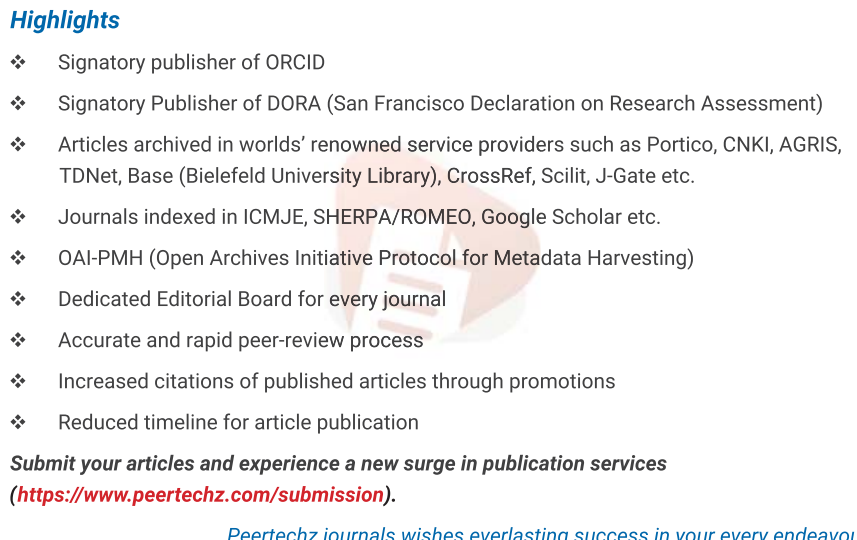

Peertechz journals wishes everlasting success in your every endeavours.

Copyright: ( 2020 Lee $\mathrm{R}$, et al. This is an open-access article distributed under the terms of the Creative Commons Attribution License, which permits unrestricted use distribution, and reproduction in any medium, provided the original author and source are credited. 